\title{
Recovery of an estuary in the southwest coast of India from tsunami impacts
}

${ }^{*}$ C. M. Laluraj, V. Kesavadas, K. K. Balachandran, Vijay John Gerson, G. D. Martin, P. Shaiju, C. Revichandran, T. Joseph, M. Nair

*National Centre for Antarctic and Ocean Research, Vasco-da-Gama, Goa-403804, India E-mail: lalucm@ncaor.org

National Institute of Oceanography, Regional Centre, Dr. Salim Ali Road, P.B. No. 1913 Cochin 682018, India

\begin{abstract}
:
Water quality in the Cochin Estuary, southwest coast of India during the tsunami attack was assessed and compared with the pre and post tsunami characteristics. From the results obtained, it is evident that a drastic change in hydrography has been inflicted by the energy transferred through the tsunami, which disturbed the entire estuarine embayment. However, the post tsunami water quality showed normal levels indicating that the region has recovered from the tsunami impacts.
\end{abstract}

Keywords: Cochin Estuary, Southwest coast of India, Tsunami impacts, Water quality 


\section{Introduction:}

The great Indian Ocean Tsunami of December 2004 generated due to the Earthquake off the west coast of Sumatra, Indonesia was among the deadliest disasters in modern history. This tsunami devastated the shores of Indonesia and several Southeast Asian countries including India. A significant enrichment in nutrients in the coastal waters of Dakshin Kannada (west coast of India) has been reported following the tsunami (Reddy et al., 2005). Cochin Estuary (connected to the Arabian Sea through a $450 \mathrm{~m}$ wide opening at Cochin) has also experienced the ferocity of this tsunami. An attempt has been made here to assess the impacts of tsunami on the hydrochemistry of Cochin Estuary.

\section{Data and methodology:}

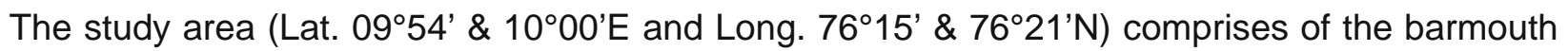
(station 1) in the harbour area, Bolghatty (5 km northeast of barmouth; station 2) and Thevara (10 km southeast of barmouth; station 3) in Cochin estuary (Fig. 1). Hydrographic observations were carried out at these stations on 30th December 2004. At station 1 sampling was carried out over two consecutive tidal cycles (two samples each during ebb and flood tide). The tide gauge record at Cochin Port showed unusual water level variations due to tsunami at frequent intervals with varying amplitudes from 26 to 30 December 2004 (Fig. 2). Hence, the observations on 30th December 2004 are considered to represent the tsunami period.

Water samples were collected from $0.5 \mathrm{~m}$ below surface using Niskin Sampler and kept in freeze till analysis in the shore laboratory. The light transparency was measured using a seechi disc. Salinity was determined using electrodeless induction salinometer (DIGI AUTO 3G, accuracy \pm 0.001). For pH measurements, an ELICO LI 610 model pH meter (accuracy \pm 0.01 ) was used. Dissolved oxygen was estimated using Winkler titration method. Water samples were filtered and analysed for nitrate, nitrite, silicate, phosphate and ammonia using spectrophotometer (Shimadzu UV- 1650PC) following standard procedures (Grasshoff et al., 1983). Analytical reproducibility was checked by performing triplicate analyses for each sample and is presented here by the average value. The water quality characteristics of Cochin Estuary during the tsunami period are compared with the data available from the same region before tsunami (December 2003 and 22nd December 2004) and after tsunami (March, 2005) periods collected from the ongoing modeling studies. 


\section{Results and discussion:}

The water quality data of the study region during pre and post tsunami periods are presented in Fig. 3. The water column generally remained thermally homogenous (average $29.8^{\circ} \mathrm{C}$ ) in correspondance with air temperature (average $29.9^{\circ} \mathrm{C}$, Fig. 3). The water temperature was lowered considerably during tsunami (average $27.7^{\circ} \mathrm{C}$ ) as compared to air temperature (average $29.9^{\circ} \mathrm{C}$ ). The surface salinity gradually decreased from barmouth towards st. 2 and 3 during pre and posttsunami periods (20.5-35.8). But the tsunami erroded this gradient quickly, as the entire estuarine region was dominated by high saline water mass (34.2-35.2). The high turbidity caused by the tsunami is evident from the reduced water transparency during tsunami (seechi depth: $0.3 \mathrm{~m}$ to $0.8 \mathrm{~m}$ ) compared to pre tsunami $(1.7 \mathrm{~m}$ to $3.0 \mathrm{~m}$ ) and post tsunami $(1.3 \mathrm{~m}$ to $1.8 \mathrm{~m})$. $\mathrm{pH}$ also showed a marginal increase during tsunami (8.28-8.45, Fig. 3). However, when compared to pre- $(4.7-5.3 \mathrm{ml} / \mathrm{l})$ and post-tsunami $(4.6-5.0 \mathrm{ml} / \mathrm{l})$ periods, the changes in dissolved oxygen level were marginal (4.0-4.5 $\mathrm{ml} / \mathrm{l})$ during tsunami. There was a sharp rise in the phosphate concentration during tsunami $(2.5-4.7 \mu \mathrm{M})$ as compared to pre-tsunami $(0.9-$ $1.5 \mu \mathrm{M})$ and post-tsunami $(0.7-1 \mu \mathrm{M})$ periods. The nitrate concentration was also conspicuously high during tsunami $(26.6-30.4 \mu \mathrm{M})$ as compared to those during pre tsunami $(6.3-9.9 \mu \mathrm{M})$ and post tsunami $(5.2-9.1 \mu \mathrm{M})$ periods. Silicate showed similar trends with higher values (35.0$42.2 \mu \mathrm{M})$ during tsunami period than the values during pre $(9.8-23.4 \mu \mathrm{M})$ and post tsunami $(10.2-13.4 \mu \mathrm{M})$ periods. The high ammonia $(87.9-93.3 \mu \mathrm{M})$ in the entire study area during the tsunami compared to the levels before and after tsunami $(4.1-68.8 \mu \mathrm{M}$ and $6.3-43.2 \mu \mathrm{M}$ respectively) is conspecusous. Cochin Estuary is reported to contain variable concentrations of nutrients (Haridas et al., 1973; Qasim and Madhupradhap, 1979; Sarala Devi et al., 1979, 1983, 1991; Sankaranarayanan et al., 1986; Dinesh Kumar et al., 1994; Balachandran, 2001.). In contrast, the homogenous water mass containing consistently high concentrations of these nutrients in the entire study region during tsunami event could indicate the extent of local disturbance it created. However, the post tsunami observation showed normal levels indicating that the region has recovered from the tsunami impacts.

\section{Conclusion:}

The present study observed drastic changes in estuarine water quality (high saline, turbid, cool and nutrient-rich water mass) generated by the tsunami through a massive inflow of coastal waters and the local disturbance it created. The turbidity was caused by the churning up of the sea-bed by the intense energy transferred by tsunami. The withdrawal of sea before the 
advancement of the tsunami could be another factor supporting the bedload sediments to get suspended along with lashing waves. This turbid water as it advanced into the estuary, released excess nutrients into the water column. Hence, the effect of tsunami on biological activities will be an interesting aspect to examine. An enhancement in the primary and secondary production could be expected following the nutrient enrichment in the study region. Even though migration of marine fishes into Cochin Estuary is a common feature, the tsunami period seems to support an increased migration of fishes into the estuary (Fig. 4). Whether the migration was as an evasive action or in trace of better feeding grounds, are to be examined critically. To sum up, the recovery of the estuary from tsunami impacts was fast, as revealed by the quick regain of the water quality to ambience during post tsunami.

\section{Acknowledgments:}

We thank Sh. Rasik Ravindra, Director, National Centre for Antarctic and Ocean Research, Goa, Dr. S.R. Shetye, Director, National Institute of Oceanography, Goa and Dr. C.T. Achuthankutty, Scientist-in-Charge, NIO, Regional Centre, for the encouragement and help. We are grateful to ICMAM-PD, Chennai for the financial support provided under the project "Ecosystem modeling of Cochin backwaters". We thank Cochin Port Trust, Cochin for providing the automatic tide gauge data. The positive journal corrections have improved the clarity of the manuscript. This is NIO contribution No. 4111. 


\section{References}

Balacndran, K.K. (2001). Chemical oceanic studies of the coastal waters of Cochin, Ph.D. Thesis (unpublished), Cochin University of Science and Technology, 250.

Dinesh Kumar, P.K., Sankaranarayanan, V.N., \& Saraladevi, K. (1994). Cochin backwaters: An introduction to the system, prior studies, Historical trends and future implications. Journal of Environmental Protection, 14(2), 98-102.

Haridas, P., Madhupradhap, M., \& Rao, T.S.S. (1973). Salinity, Temperature, Oxygen and Zooplankton biomass of the backwaters from Cochin to Alleppey. Indian Journal of Marine Sciences, 2, 94-102.

Grasshoff, K., Ehrhardt, M., \& Kremling, K. (eds) (1983). 2nd edn., Method of seawater analysis, (p. 419) Weinheim; Deerfeild Beach, Florida Basel, Vorlagchemie. Qasim, S.Z., \& Madhupradhap, M. (1979). Changing ecology of Cochin Backwater. Contribution to Marine Science, 137- 142.

Reddy, H.R.V., Katti, R.J., Raveesha, K.P., Vikas, S.J.,\&Nagendra babu, K.S. (2005). Coastal water quality off Dakshina Kannada before and after tsunami. Current Science, 88 (7), 10291027.

Sankaranarayan, V.N., Udaya Varma, P., \& Balachandran, K.K. (1986). Estuarine characteristics of the lower reaches of the river Periyar (Cochin backwaters). Indian Journal of Marine Sciences, 15(3), 45-48.

Sarala Devi, K., Venogopal, P., Remani, N., Lalitha, S., \& Unnithan, R.V. (1979). Hydrographic features and water quality of Cochin backwaters in relation to industrial pollution. Indian Journal of Marine Sciences, 8, 141- 145.

Sarala Devi, K., Venogopal, P., Remani, N., Dominic, Z., \& Unnithan, R.V. (1983). Nutrients in some estuaries of Kerala, Mahasagar-Bulletin of National Institute of Oceanography, 16(2), 161-173.

Saraladevi, K., Jayalakshmi, K.V., \& Venugopal, P. (1991). Distribution of nutrients in Periyar river estuary. Indian Journal of Marine Sciences, 20(4), 141-145. 


\section{Legends to figures:}

Fig. 1 Study region showing station locations in the Cochin Estuary

Fig. 2 Changes in mean sea level during December 2004, recorded at Cochin Harbour

Fig. 3 Physico-chemical characteristics in the study region before, during and after tsunami (Station No. in X-Axis)

Fig. 4 Estuarine migration of fishes captured through the Chinese dipnets near station 3 during tsunami period 


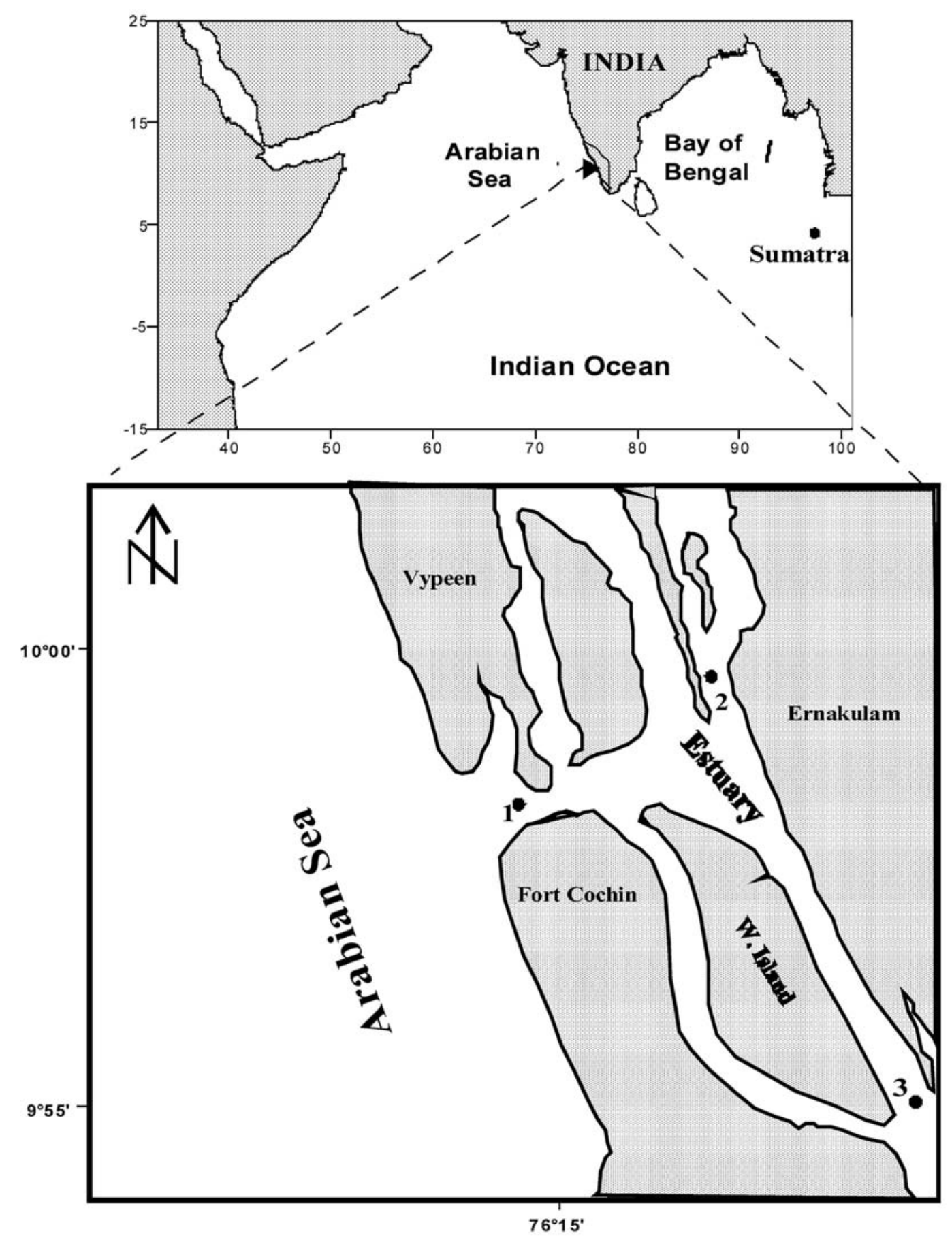

Fig -1 


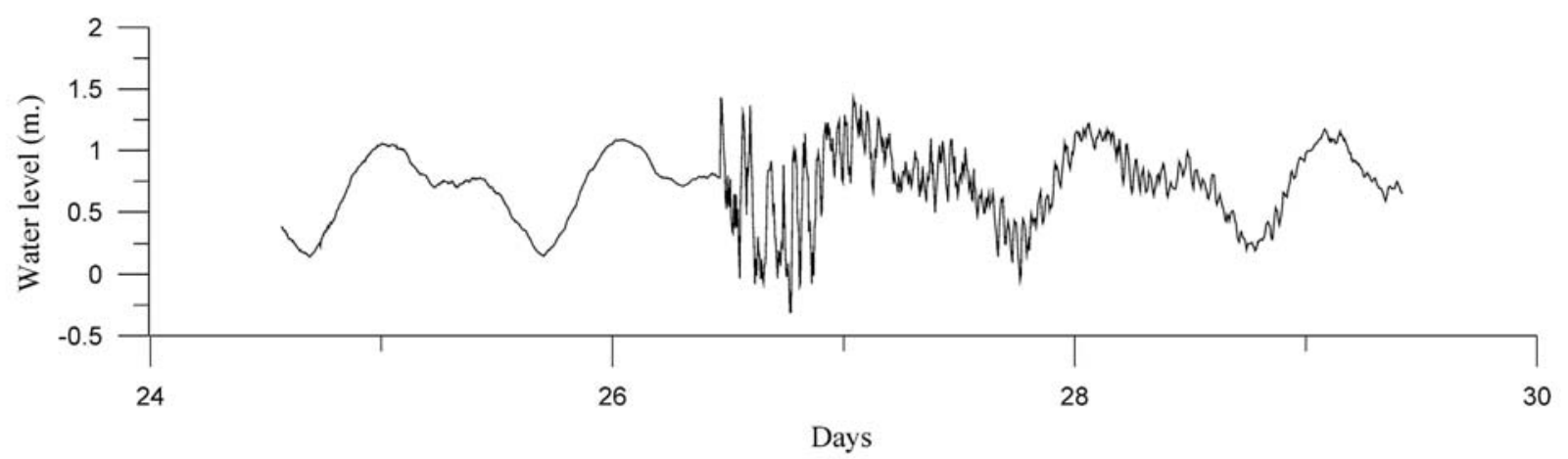

Fig -2 

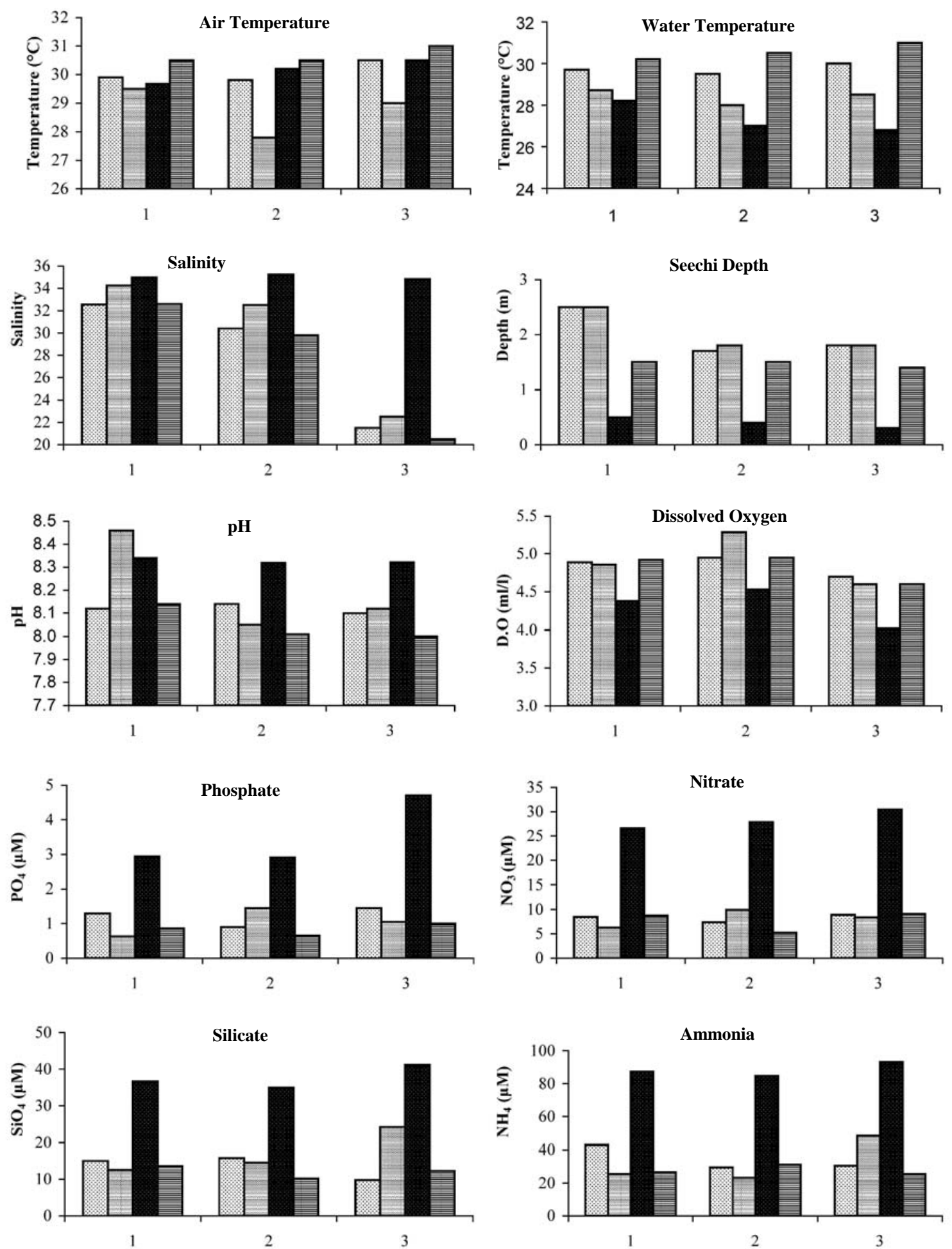

December 2003

30th December

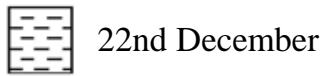

March 2005

Fig -3 


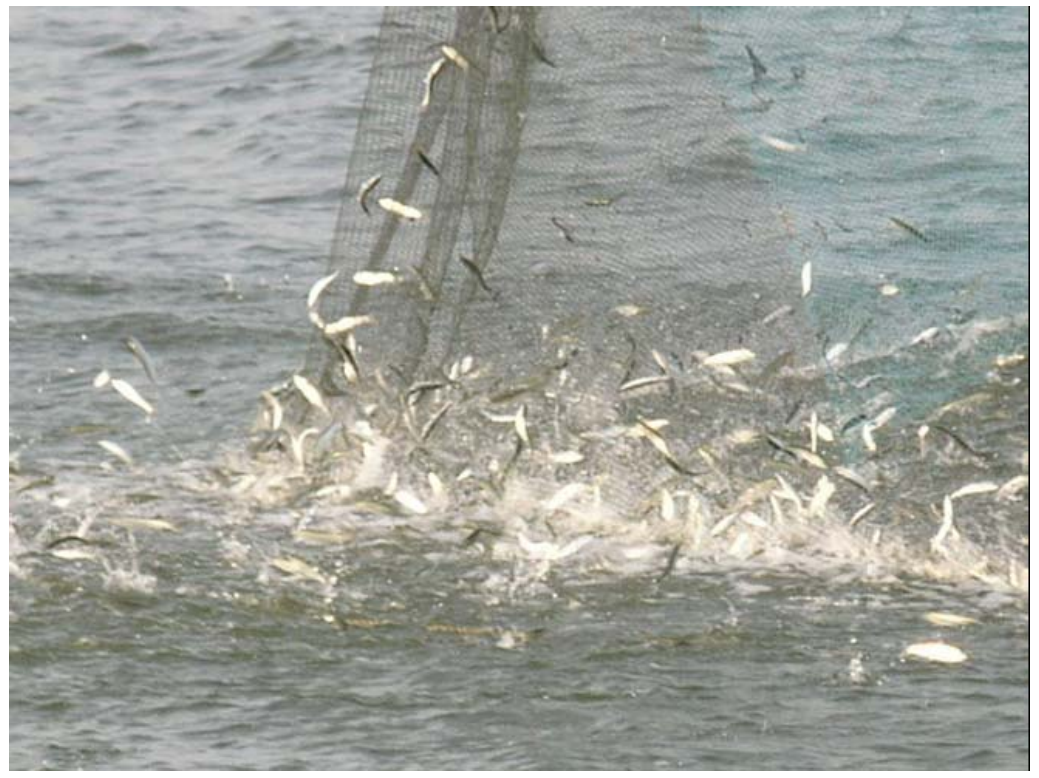

Fig - 4 